and understood already that we need routine observations solely to set against established base-lines. Nothing could be further from the truth. For a variety of reasons, not least the scale of effort required and the pursuit in recent decades of more fashionable fields or quick results, we know very little about the extent and causes of natural fluctuations. Nor are we within sight of being able to predict the probable biological repercussions of the elimination or weakening (through pollutants) of one or two "key" species in marine communities. A massive new programme of fundamental research is required to establish the base-lines of natural variation, and its essential basal requirement is routine, long-term field observation and measurement. The point where such activity becomes "routine" in the perjorative sense and contributes little to research is far distant.

If, however, base-line studies are seen as merely the collection of numerical data at particular sites in anticipation of a possible pollution incident, and if such data are not used to further our understanding of natural variation, you are correct to feel that this activity does not qualify as research. If it is considered necessary, and this I doubt in most cases, the problems of who does it and finances it have yet to be faced; but it seems most unlikely that universities will accept it as a just demand on their limited research time and facilities.

Yours faithfully,

J. R. LEwIS

Wellcome Marine Laboratory,

Robin Hood's Bay,

Yorkshire.

\section{Sir William Grove}

SiR,--In your issue of January 24, 1970, there appeared an extract from Nature of 100 years ago consisting of a letter from Sir W. R. Grove concerning the correlation of physical forces. The following footnote to the letter was appended: From a letter to the Editor, Nature, 1, 335, January 27, 1870. Grove was the first to demonstrate the electrolytic decomposition of water.

The Dictionary of National Biography gives the dates of birth and death of Sir W. R. Grove as July 11, 1811, and August 1, 1896, respectively. If these particulars are correct, Sir W. R. Grove could hardly have been the first to demonstrate the electrolyte decomposition of water, as the first mention of this having been accomplished was in Nicholson's Journal, 4, 183 (1800), which was an account of experiments done by W. Nicholson and Sir A. Carlisle.

\section{Yours faithfully,}

SydNEy GILI

University of Manchester

Institute of Science and Technology.

\section{The Social Sciences}

SiR,--In "Miscellaneous Intelligence" for January 31 (Nature, 224,$405 ; 1970$ ) you state: "if any of the social sciences is a science, social anthropology is, ...". A more preposterous statement is difficult to imagine. Surely that must have been written by one of the visionary prophets of the sect. It is not rigour that is exhibited by the long period of introspection between field work and publication, but an inability to apply anything like scientific method to the materials. I think you owe an apology to anthropological linguists, physical anthropologists, and archaeologists, who exhibit some measure of the rigour of science and its methods.

$$
\begin{aligned}
& \text { Yours faithfully, } \\
& \text { JoHN BUETTNER-J ANUSCH }
\end{aligned}
$$

Duke University Medical Center,

Durham,

North Carolina.

\section{British Diary}

\section{Monday, February 23}

Genius in Science (5 p.m.) Professor Michael Polanyi, London Sichool of Economics and Political Science, at Houghton Street, Aldwych, London WC2. Modern Mixing Systems $(6.45$ p.m.) Mr P. Whitaker, Institution of the

Terminal Units and Transmission in Electronic Telephone Exchanges (5.30 p.m.) Mr T. H. Flowers, Institution of Electrical Engineers, at $(5.30 \mathrm{p} . \mathrm{m}$.$) Mr T. H. Flowe$
Savoy Place, London WC2.

The Mechanical Equipment for the Construction of the Victoria Line (6 p.m. discussion) Institution of Mechanical Engineers, at 1 Birdcage Walk, London SW1.

Thermoplastics in the Cable Industry $(7.30 \mathrm{p.m}.) \mathrm{Mr} \mathrm{R}$. H. Greenhalgh, Plastics Institute, at the Stork Hotel, Queen Square, Liverpool.

Tuesday, February 24

Design of Pressure Vessel Components (all-day discussion) Institution of Mechanical Engineers, at 1 Birdcage Walk, London SW1.

Electrolyte Movements within the Colon (5.30 p.m.) Professor O. M. Wrong, University of London, at the Institute of Child Health, 30 Guilford Street, London WC1. (Fourteenth of fifteen lectures on "The Scientific Basis of Medicine".)

Excavations at Swanscombe 1968-69 (5.45 p.m.) Dr J. Waechter, University of London, at the Institute of Archaeology, 31-34 Gordon Square, London WC1.

Some New Concepts in Polymer Stabilization (6 p.m.) Professor G. Scott, Society of Chemical Industry, Plastics and Polymer Group, at 14 Society of Chemical Industry,
Belgrave Square, London SW1.

The Content of Measurements Courses for Electrical Engineers (5.30 p.m. discussion) Institution of Electrical Engineers, at Savoy Place, London WC2.

Yorkshire's Pink Gold-Its Discovery, Exploitation and Evaluation, Mr L. S. Phillips; The Analysis of Crude Potash Materials, Dr J. M. Skinner (8 p.m.) Society for Analytical Chemistry; and the Borough Road, Middlesbrough.

Wednesday, February 25

Hi-Fi (6.30 p.m.) Mr J. Moir, Institution of Electrical Engineers, at King Edward VI Grammar School, Chelmsford.

Investigation into the Permeametry and Crystal Structure of Fats and Fat Blends, Mr G. C. Evans; The Use of Low Resolution NMR for the Rapid Determination of Solids Content of Fat Blends, at 14 Belgrave Square, London SW1.

Kinetics and Regulation of Erythropoiesis (2 p.m.) Dr L. G. Lajtha University of London, at the Royal Postgraduate Medical School, Du Cane Road, London W12.

Low Light Television Tubes (6 p.m.) Dr P. L. Batey, Institution of Electronic and Radio Engineers, at 9 Bedford Square, London WC1.

Man, Mind and Machine (1.10 p.m.) Professor Philip M'Pherson, City University, at the Graduate Business Centre, Gresham College, Basinghall sity, at the Graduate

Maps as a Medium of Scientific Information (1 p.m.) Royal Institution, History of Science Discussion Group, at 21 Albemarle Street, London W1

Newer Techniques of Thermal Analysis with special reference to Calorimetry (2.30 p.m.) Society for Analytical Chemistry; and the Chemical Society, in the Department of Chemistry, University of Keele, Staffs.

Stereophonic Transmission $(7.30$ p.m.) Dr G. J. Phillips, Institution of Electrical Engineers, at the Star and Garter Hotel, Dorking, Surrey. Sterilizable Plastics Packaging for Foodstutrs (10.30 a.m. symposium)
Society of Chemical Industry, in the Meeting Room of the Zoological Society of London, Regent's Park, London NW1.

The Application of Test Results to the Calculation of Short-circuit Levels in Large Industrial Systems with Concentrated Induction Motor Loads (5.30 p.m.) Mr C. B. Cooper, Dr D. M. McLean and London WC2.

The Direct Determination of Oxygen in Organic Compounds (6.30 p.m.) Mr P. Gouverneur, Society for Analytical Chemistry, at the Leicester Lounge, Glasshouse Street, London W1.

The Interaction of Power Supply Systems and Digital Equipment in Aircraft (6 p.m. discussion) IEE/RAeS, London Joint Group, at the Royal Aeronautical Society, 4 Hamilton Place, London W1.

The Neuropharmacology of Sleep (5.30 p.m.) Professor M. Jouvet (Lyon), University of London, at Charing Cross Hospital Medical School, Chandos Place, London WC2.

Trends in Diffusion (two-day conference) Institute of Physics and the Physical Society; The Institute of Metals; and the National Physical Laboratory, at the NPL, Teddington, Middlesex.

\section{Thursday, February 26}

Ammonium Nitrate Production $(6.30$ p.m. $)$ Mr R. Carter, Institution of Chemical Engineers, at I.C.I., Ltd, Billingham.

Architectural Aerodynamics ( 9.30 a.m., two-day meeting) Royal Society, at 6 Carlton House Terrace, London SW1.

Medical Problems of Cold Immersion (5.30 p.m.) Dr W. R. Keatinge, University of London, at the Institute of Child Health, 30 Guilford Street, London WC1. 